\title{
Antimycotic potential of Kawayang tinik against pathogenic fungal species
}

\author{
Abegail G. Saducos \\ College of Arts and Sciences, Tarlac Agricultural University, Camiling, Tarlac, Philippines, 2306 \\ *Email: asaducos@tau.edu.ph
}

\section{ARTICLE HISTORY}

Received: 15 January 2021

Accepted: 17 April 2021

Published: 01 May 2021

\section{KEYWORDS}

Bambusa blumeana

Antifungal assay

Agar well diffusion

Aspergillus niger

Penicillium chrysogenum
ABSTRACT

The importance of discovering and obtaining new, natural and sustainable sources of potential drugs have been the focus of scientific communities due to the emergence of increasing cases of microbial resistance, one of the biggest health threats in our society today. This study aimed to determine the antimycotic potential of Bambusa blumeana (kawayang tinik) specifically its leaf, rhizome, root, inner culm and outer culm extracts using the agar well diffusion assay. Results of the study revealed that all kawayang tinik extracts produced statistically equal size zone of inhibition (ZOI) against Aspergillus niger at $1 \mathrm{mg} / \mathrm{ml}$ concentration while the ethanolic root and leaf extracts showed larger ZOI against Penicillium chrysogenum compared to other kawayang tinik extracts. Furthermore, the results of the antifungal assay showed comparable activity of kawayang tinik extracts to Fluconazole, a pharmaceutically approved antifungal drug, at $1 \mathrm{mg} / \mathrm{ml}$ concentration. Phytochemical studies further revealed the presence of alkaloids, tannins, phenols, sterols, triterpenes and flavonoids in its different parts which may support its potential antimycotic properties.

\section{Introduction}

The Center of Disease and Prevention (CDC) and World Health Organization (WHO) considers antibiotic resistance, in both bacterial and fungal species, as one of the biggest public health threats today $(1,2)$. Accordingly, widespread occurrences of antibiotic resistance were recorded among 500000 people across several countries including Asia. It is due to this fact that scientific communities are gearing towards drug discovery especially those coming from natural, highly available and sustainable resources.

Plants have been known for ages to contain bioactive compounds that possessed disease - fighting and ailment - preventing capabilities. In fact, the use of plants as ethnobotanical - based remedies and medication for various illnesses have been a longdated tradition not only in the Philippines, but in other countries as well (3-5). Moreover, most of the pharmaceutical products being sold in the market today were obtained and patterned from bioactive compounds found in plants and plant products.
The bamboo plant was traditionally utilized to make home furniture and its shoots were usually obtained for food. However, secondary to technological advances in phytochemical screening and testing, several bamboo species are now being studied and observed as potential sources of new pharmacotherapeutic products. Leaves and shoot extracts from bamboo species such as Bambusa balbacooa, Bambusa bambos, Dendrocalamus hamiltonii, Bambusa vulgaris and Bambusa vulgaris exhibited potential antimicrobial properties against several pathogenic microorganisms, bacterial and fungal alike (6-14). Leaf extracts of Dendrocalamus strictus were also cited to show antimycotic potentials against pathogenic fungal strains such as Aspergillus niger, Penicillium chrysogenum, Aspergillus flavus and Fusarium moniliforme (15). It was further observed that the antimicrobial activities in bamboo plants can be detected in the entirety of the plant, specifically in the branches, roots, knots, inner culms and rhizomes and not only on the leaf and shoot parts which are the most common plant parts used in antimicrobial studies involving bamboo plants (16).

(c) Saducos (2021). This is an open-access article distributed under the terms of the Creative Commons Attribution License, which permits unrestricted use, distribution and reproduction in any medium, provided the original author and source are credited (https://creativecommons.org/licenses/by/4.0/).

To cite this article: Saducos A G. Antimycotic potential of Kawayang tinik against pathogenic fungal species. Plant Science Today. 2021;8(2):403-409. https://doi.org/10.14719/pst.2021.8.2.1093 
The Bambusa blumeana, also known as spiny bamboo or thorny bamboo, is a species of bamboo occurring in tropical Asia and is abundant in the Philippines. This bamboo species is known locally as 'kawayang tinik' and ethnobotanically known as 'kawayan siitan' for Ilocanos and 'kawayang batakan' for Bisayans. Although widely available in the community and also tagged as the top economically important bamboo species in the Philippines (17), very few research studies and literatures, both local and international, have been published providing information on its biological activities especially with regard to its potential antimycotic properties.

With various evidences citing the potential biological activity in several bamboo plants against pathogenic fungal species, the present study determined the innate antimycotic potentials of $B$. blumeana (kawayang tinik). Specifically, the study explored the following:

1. Presence of potential antifungal activity in Bambusa blumeana (kawayang tinik) against Aspergillus niger and Penicillium chrysogenum.

2. Differences in the antifungal properties of the ethanolic and aqueous extracts of Bambusa blumeana (kawayang tinik) in terms of its different plant parts including the leaf, rhizomes, roots and inner and outer culms.

3. Identified different phytocompounds in various B. blumeana (kawayang tinik) extracts.

\section{Materials and Methods}

\section{Selection, Gathering and Preparation of Plant Extracts}

Plant parts such as leaves, rhizomes, roots, inner and outer culms were identified and gathered from locally - grown B. blumeana (kawayang tinik) plants found at Tarlac Agricultural University (TAU) Bamboo Forest Park located in Sitio Calao, Mayantoc, Tarlac. Collected parts were initially washed and cleaned with tap water to remove majority of the dirt and debris while distilled water was used for the final washing. Clean plant specimens were afterwards air dried and powdered separately using electric blender and corn miller. Individual powderized plant parts were placed in clean, zip locked containers, labelled and stored in the refrigerator with temperature regulation at $4{ }^{\circ} \mathrm{C}$ until further use $(14,18,19)$.

Powdered plant parts for ethanolic extraction were then mixed and macerated for $48 \mathrm{hrs}(12,16$, 20 ) at room temperature using $95 \%$ ethanol utilizing 1: 4 extract to solvent ratio to produce ethanolic extracts. As for the preparation of aqueous extracts, $400 \mathrm{ml}$ of distilled water was added with $100 \mathrm{gm}$ of individual powdered dry plant parts (leaves, roots, rhizomes, inner and outer culms). Afterwards the individual aliquots were boiled at $80{ }^{\circ} \mathrm{C}$ for at least 15 min. cooled and allowed to macerate for $24 \mathrm{hrs}$ (16, 21, 22).

Frequent agitation of the solutions was observed during the course of the maceration period to further facilitate the extraction of potential bioactive compounds (20). After maceration, the aqueous and ethanolic solutions were filtered using Whatman filter paper No. 1. The filtrates were exposed thereafter to rotary evaporation to remove the solvents and concentrate the extracts.

Stock solutions were then formulated to $1 \mathrm{mg} / \mathrm{ml}$ concentration and sterility- proofed through filtration of individual plant extracts using sterile millipore filter syringe (Whatman ${ }^{\circledR}$ at 0.22 millipore size) connected to a sterile syringe and test tube (23). The filtered sterile extracts contained in sterile tubes are then stored in the refrigerator with temperature regulation at $4{ }^{\circ} \mathrm{C}$ until needed for antimicrobial assay (24).

\section{Antifungal Assay}

Pure cultures of pathogenic fungi (Aspergillus niger and Penicillium chrysogenum) from the College of Arts and Sciences of Benguet State University located La Trinidad, Benguet were used to test the antifungal property of different kawayang tinik extracts.

Agar well diffusion method was utilized to determine the biological activity of $B$. blumeana (kawayang tinik) against $A$. niger and $P$. chrysogenum. In this method, a $3 \mathrm{~mm}$ diameter fungal or mycelium disk was placed at the center of the petri dish while various kawayang tinik extracts were placed in wells distributed in even distances around the fungal disk culture (Fig. 1). Fluconazole 1 $\mathrm{mg} / \mathrm{ml}$ was used as positive control while sterile water and $95 \%$ ethanol were used as negative controls. After $72 \mathrm{hrs}$ of room incubation, antifungal activity was determined by measuring the inhibition zones formed between the extracts and the mycelium disk. The zone of inhibition (ZOI) is measured by obtaining the distance of mycelium growth from the disk towards the individual kawayang tinik extracts as indicated by the blue line (Fig. 1). As shown by various studies, mycelium or fungal species grown on

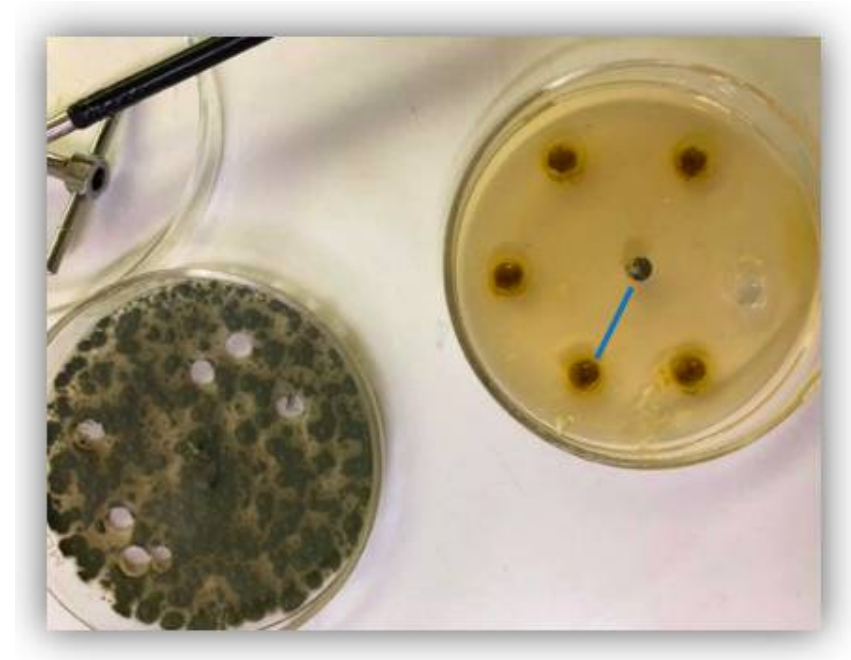

Fig. 1. Antifungal assay using agar-well diffusion method.

laboratory agar tend to deviate from extracts containing antimycotic compounds, thus, minimal growth between the disk and the wells containing the individual extracts may possibly correlate to presence of bioactive compounds responsible for antifungal mechanisms (25-28). Additionally, five 
replications were made per treatment per fungal species.

\section{Phytochemical testing}

Individual kawayang tinik plant extracts are subjected to qualitative phytochemical screening to determine the presence or absence of various phytocompounds using prescribed techniques and procedures $(10,29,30)$. The presence of alkaloids was tested using different reagents (Mayer, Wagner, Bouchardat and Valser) while sterols and triterpenes were tested using the Lieberman's Buchard Test. The presence of flavonoids were otherwise confirmed using the Salkowski Test and Bate- Smith Metcalf test while the presence of cardiac glycosides were tested using the Keller- Killiani Test. Froth test was utilized to observed for the presence of saponin, gelatin test and ferric chloride test for the presence of tannins and phenolic compounds, Borntrager Test for the presence of antraquinone and Guignard Test for the possible presence of cyanogenic glycosides. The results of the phytochemical testing is presented in Table 3.
Table 1. Variations in the antifungal property of Bambusa blumeana (kawayang tinik) against Aspergillus niger

\begin{tabular}{lc}
\hline \multicolumn{1}{c}{ Extracts (1 $\mathbf{~ m g} / \mathbf{m l})$} & Zone of Inhibition (mm) \\
\hline Ethanolic Roots & $1.13 \mathrm{a}$ \\
\hline Ethanolic Inner culm & $1.04 \mathrm{ab}$ \\
\hline Ethanolic Leaves & $0.98 \mathrm{ab}$ \\
\hline Ethanolic Outer culm & $0.75 \mathrm{ab}$ \\
\hline Fluconazole & $0.55 \mathrm{ab}$ \\
\hline Aqueous Outer culm & $0.47 \mathrm{ab}$ \\
\hline Aqueous Inner culm & $0.41 \mathrm{ab}$ \\
\hline Aqueous Rhizomes & $0.22 \mathrm{ab}$ \\
\hline Ethanolic Rhizomes & $0.20 \mathrm{~b}$ \\
\hline Aqueous Roots & $0.10 \mathrm{~b}$ \\
\hline Aqueous Leaves & $0.09 \mathrm{~b}$ \\
\hline Water & $0 \mathrm{c}$ \\
\hline Fluconazole & $0 \mathrm{c}$ \\
\hline F-computed value $=3.74$, F-critical value $=1.94$, Probability $=.0004$
\end{tabular}

(0.09 mm) extracts of $B$. blumeana (kawayang tinik) also showed lesser statistically comparable inhibitory activities against $A$. niger. It was further observed that the above- mentioned extracts are statistically comparable to Fluconazole, a pharmaceuticallyapproved medication and antifungal agent, at 1

Table 3. Phytochemical analysis of different Bambusa blumeana (kawayang tinik) extracts

\begin{tabular}{|c|c|c|c|c|c|c|c|c|c|c|}
\hline \multirow{3}{*}{ Bioactive Compounds } & \multicolumn{10}{|c|}{ Plant Extracts } \\
\hline & \multicolumn{5}{|c|}{ Aqueous } & \multicolumn{5}{|c|}{ Ethanolic } \\
\hline & Leaf & Rhizome & Roots & $\begin{array}{l}\text { Inner } \\
\text { Culm }\end{array}$ & $\begin{array}{l}\text { Outer } \\
\text { Culm }\end{array}$ & Leaf & Rhizome & Roots & $\begin{array}{l}\text { Inner } \\
\text { Culm }\end{array}$ & $\begin{array}{l}\text { Outer } \\
\text { Culm }\end{array}$ \\
\hline Alkaloid & + & + & + & + & + & + & + & + & + & + \\
\hline Sterol and Triterpenes & + & - & - & + & + & + & - & - & + & + \\
\hline Flavonoid & + & - & - & + & + & + & - & - & + & - \\
\hline Cardiac glycoside & - & - & - & - & - & - & - & - & - & - \\
\hline Tannins and Phenols & + & + & + & + & + & + & + & + & + & + \\
\hline Anthraquinone & - & - & - & - & - & - & - & - & - & - \\
\hline Cyanogenic Glycoside & - & - & - & - & - & - & - & - & - & - \\
\hline
\end{tabular}

\section{Results and Discussion}

One-way Analysis of Variance (ANOVA) was used to determine the variation in the antifungal property of the various plant extracts derived from the different parts of $B$. blumeana (kawayang tinik).

\section{Variations in the Antifungal Property of Bambusa blumeana (kawayang tinik) against Aspergillus niger}

Table 1 presents the variations in the antimycotic potentials of $B$. blumeana (kawayang tinik) against $A$. niger. Results showed that there are highly significant variations among the $B$. blumeana (kawayang tinik) extracts against $A$. niger in terms of plant parts and the extraction solvents used since the F- computed value (3.74) is higher than the F- critical value (1.94) and the probability is less than 0.05 .

The table further shows that in terms of the specific extracts derived from $B$. blumeana, the ethanolic root extract exhibited the highest comparable mean zone of inhibition (ZOI) at $1.13 \mathrm{~mm}$ against $A$. niger. This is followed by the extracts of ethanolic inner culm $(1.04 \mathrm{~mm})$, ethanolic leaves $(0.98 \mathrm{~mm})$, ethanolic outer culm $(0.75 \mathrm{~mm})$, aqueous outer culm $(0.47 \mathrm{~mm})$ and aqueous inner culm $(0.41$ $\mathrm{mm})$. On the other hand, the ethanolic rhizome $(0.20$ $\mathrm{mm})$, aqueous root $(0.10 \mathrm{~mm})$ and aqueous leaves $\mathrm{mg} / \mathrm{ml}$ concentration. This would imply that the extracts of $B$. blumeana have the same inhibitory effect as the standard antifungal drug Fluconazole at $1 \mathrm{mg} / \mathrm{ml}$ drug concentration (Fig. 2).

\section{Various phytocompounds were observed to be}

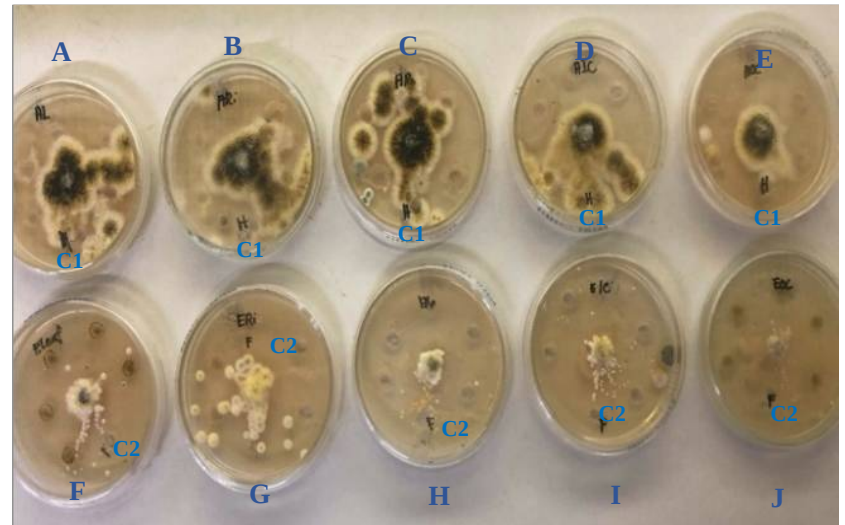

Fig. 2. Aspergillus niger growth on plates planted with various kawayang tinik extracts: (A) aqueous leaf, (B) aqueous rhizome (C) aqueous root, (D) aqueous inner culm, (E) aqueous outer culm, (F) ethanolic leaf, (G) ethanolic rhizome (H) ethanolic root, (I) ethanolic inner culm, (J) ethanolic outer culm, (C1) water and (C2) Fluconazole at $1 \mathrm{mg} / \mathrm{ml}$.

present in different species of bamboo which could possibly explain the ZOI formed by the extracts 
against $A$. niger. For instance, apigenin, luteolin and p- coumaric acid were discovered in the different parts of $P$. pubescence, specifically in its leaf, root, rhizome and culms (16). These phytocompounds were noted to have the same antimicrobial mechanisms as that of the fluconazole, a pharmaceutically - approved antifungal drug. Fluconazole as an antifungal agent exhibits its action by increasing fungal cell wall permeability and disrupting the uptake of essential nutrients needed by the cell leading to eventual death (28). Through the application of chemotaxonomy principles which states that plants that are taxonomically related contains the same biochemical compositions $(31,32)$, we could consider the possibility that kawayang tinik extracts may contain the same phytocompounds hence, justifying its potential antifungal property and the ZOI produced by its individual extracts against $A$. niger. The antimycotic potentials of bamboo species could further be claimed through the identification of another antifungal protein known called Dendrocin (33). Its mechanism of action includes the formation of membrane channels, degradation of polymers in fungal cell wall or disruption of cellular ribosomes (34).

In terms of extraction solutions used in the study, it was observed that majority of ethanolic $B$. blumeana extracts exhibited better antifungal potential compared to aqueous extracts although statistical comparability is noted among these extracts at $1 \mathrm{mg} / \mathrm{ml}$ concentration. This could be associated with the polarity of the solvents used to extract the potential phytocompounds present in the different plant parts of $B$. blumeana. Water is a pure polar solvent thus, can only attract or extract polar compounds while ethanol is less polar than water hence, it can possibly attract both polar and nonpolar compounds (35). The greater variety of phytocompounds which may be extracted via ethanolic extraction may provide explanation on the better inhibitory performance of ethanolic extracts compared to the aqueous extracts of kawayang tinik. Moreover, when plant sources are homogenized or extracted using the same protocols, the polarity of the solvent is the main factor to be considered $(36,37)$.

\section{Variations in the Antifungal Property of Bambusa blumeana (kawayang tinik) against Penicillium chrysogenum}

Table 2 presents the variations in the antifungal potential of $B$. blumeana (kawayang tinik) against $P$. chrysogenum. Results of the analysis revealed high significant variations in the antifungal potential of different $B$. blumeana (kawayang tinik) extracts against $P$. chrysogenum since the computed F-value (20.21) is higher than the F - critical value (1.94) and the probability is lower than 0.05 .

Statistical analysis further revealed that the ethanolic root and leaf extracts of $B$. blumeana exhibited the highest statistically comparable antifungal potential against $P$. chrysogenum both with mean ZOI of $1.59 \mathrm{~mm}$. These were followed by kawayang tinik extracts of ethanolic inner culm $(0.48$ $\mathrm{mm})$, ethanolic rhizome $(0.41 \mathrm{~mm})$, ethanolic outer culm $(0.12 \mathrm{~mm})$, aqueous inner culm $(0.06 \mathrm{~mm})$ and
Table 2. Variations in the antifungal property of Bambusa blumeana (kawayang tinik) against Penicillium chrysogenum

\begin{tabular}{lc}
\hline \multicolumn{1}{c}{ Extracts (1 $\mathbf{~ m g / m l ) ~}$} & Zone of Inhibition (mm) \\
\hline Ethanolic Roots & $1.59 \mathrm{a}$ \\
\hline Ethanolic Leaves & $1.59 \mathrm{a}$ \\
\hline Ethanolic Inner culm & $0.48 \mathrm{~b}$ \\
\hline Ethanolic Rhizomes & $0.41 \mathrm{~b}$ \\
\hline Ethanolic Outer culm & $0.12 \mathrm{~b}$ \\
\hline Aqueous Inner culm & $0.06 \mathrm{~b}$ \\
\hline Aqueous Rhizomes & $0.03 \mathrm{~b}$ \\
\hline Aqueous Leaves & $0 \mathrm{c}$ \\
\hline Aqueous Roots & $0 \mathrm{c}$ \\
\hline Aqueous Outer culm & $0 \mathrm{c}$ \\
\hline Water & $0 \mathrm{c}$ \\
\hline Fluconazole & $0 \mathrm{c}$ \\
\hline F-comput valu
\end{tabular}

F-computed value $=20.21$, F-critical value $=1.94$. Probability $=1.75 \mathrm{E}-17=.0000$

Note: Means followed by the same letter/s are not significantly different at $5 \%$ level

aqueous rhizome $(0.03 \mathrm{~mm})$ which are comparable or having equal antifungal effects against $P$. chrysogenum at $1 \mathrm{mg} / \mathrm{ml}$ concentration. On the contrary, the aqueous extracts of leaves, roots and outer culm did not exhibit any effects against $P$. chrysogenum exhibiting mean ZOI of $0.00 \mathrm{~mm}$ (Fig. 3).

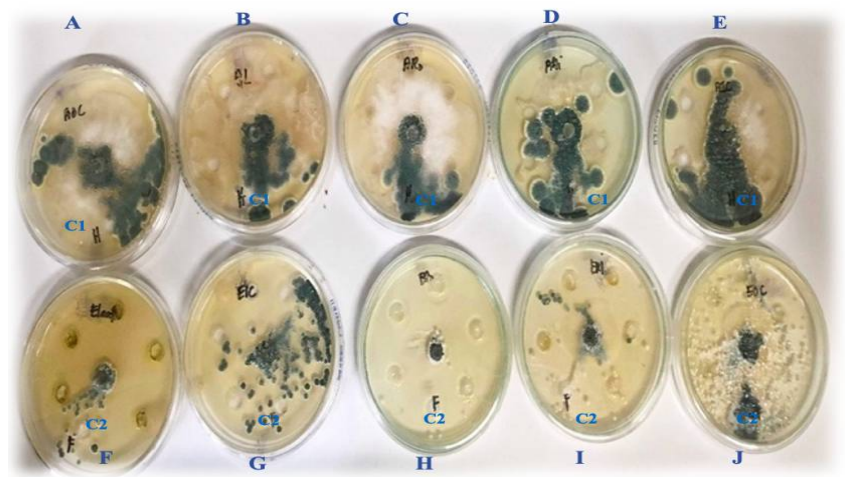

Fig. 3. Penicillium chrysogenum growth on plates planted with various kawayang tinik extracts: (A) aqueous outer culm, (B) aqueous leaf (C) aqueous root, (D) aqueous rhizome, (E) aqueous inner culm, (F) ethanolic leaf, (G) ethanolic inner culm (H) ethanolic root, (I) ethanolic rhizome, (J) ethanolic outer culm, (C1) water and (C2) Fluconazole at $1 \mathrm{mg} / \mathrm{ml}$.

As observed in the study, ethanolic extracts produced higher mean ZOI compared to the aqueous extracts of inner culm, rhizome, leaves, roots and outer culms that exhibited mean ZOI of $0.06 \mathrm{~mm}, 0.03$ $\mathrm{mm}$ and $0.00 \mathrm{~mm}$ respectively. This result could still be associated to the polarity of extraction solutions used in the study whereby ethanol being less polar could harness both polar and non- polar compounds while water, a pure polar solvent, could only harness polar phytocompounds (37). Since ethanolic extraction could harness a wider variety of phytocompounds, better inhibitory potentials could be observed compared to aqueous extracts. Moreover, the better inhibitory performance of the ethanolic extracts could also indicate the possibility of greater proportions or amount of non- polar phytocomponents residing in the different plant parts of kawayang tinik especially that aqueous counterparts does not exhibit any inhibitory effects against $P$. chrysogenum (i.e. aqueous roots, leaves and outer culms producing mean ZOI of $0.00 \mathrm{~mm}$ ). 
The findings mentioned may also be correlated a previous study result wherein it was observed that phytocomponents from the leaf extracts of bamboo species Phyllostachys and Moso bamboo are not water soluble (38). However, the presence of polar phytocompounds in the different parts of $B$. blumeana could not be totally eliminated from the current study since aqueous extracts also exhibited zones of inhibitions against the previously discussed fungal species. It could be a possibility that the either $P$. chrysogenum is resistant to the polar compounds present in the different extracts of kawayang tinik or the concentration of extracts which is $1 \mathrm{mg} / \mathrm{ml}$ is inadequate to show inhibitory action against the said fungal species. Therefore, additional and more advanced studies should be conducted to fully determine the various phytocomponents present in the different parts of $B$. blumeana and how these phytocompounds relates to the antifungal potentials of kawayang tinik as well as devise further experimentations catering to different concentrations of extracts against fungal species.

The results of the study also coincide with previous findings citing that various phytocomponents were present in the different parts of the bamboo species $P$. pubescence (16). Specifically, apigenin and tricin derivatives were noted to be abundant in the root and leaf part of the said bamboo species. Antifungal mechanisms of these identified phytocompounds were noted to be fungal membrane and metabolic disruption $(38,39)$ the same inhibitory action of fluconazole, a standard antifungal drug (28).

Currently, there are no standard medical treatment of choice for the management of penicilliosis, however, antibiotics like amphotericin $\mathrm{B}$, itraconazole, or fluconazole were reported to be effective against the said organism. The various ranges of inhibition zones exhibited by the ethanolic extracts of $B$. blumeana may indicate potential effectiveness of the said bamboo species in inhibiting the fungi $P$. chrysogenum, especially that the ethanolic root and leaf extracts exhibited more significant results compared to the standard antibiotic treatment Fluconazole at $1 \mathrm{mg} / \mathrm{ml}$ concentration. Moreover, other $B$. blumeana plant parts such as rhizomes and culms also exhibited potential antifungal activities as evidenced by the inhibition zones formed which further highlights the potential of the said bamboo species as source of potential antifungal drug against $P$. chrysogenum.

\section{Phytochemical Testing}

Table 3 shows the results of the phytochemical test involving different extracts of kawayang tinik. As shown, it is evident that all of the extracts contain bioactive compounds such as alkaloid, tannins and phenols while majority of the extracts also contains sterols and flavonoids. On the other hand, all of the extracts were screened negative for the presence of cardiac glycoside, saponins, anthraquinone and cyanogenic glycoside.

The presence of various phytochemicals in the ethanolic and aqueous extracts and their innate abilities to promote microbial inhibition may possibly verify the antimycotic potentials of kawayang tinik extracts. Alkaloid as a phytocompound exerts its antimicrobial mechanism via multitarget action such as outer membrane or cytoplasmic membrane disruption, cellular respiratory inhibition and nucleic acid synthesis or cell division inhibition $(39,40)$. Flavonoid, on the other hand, is able to promote inhibition of nucleic acid synthesis and disrupt the energy metabolism in pathogenic microorganisms (39). Tannins are also able to induce inhibition of bacterial and fungal enzymatic activity via direct interference on the microorganism's metabolism while triterpenes and sterols work by increasing the tolerance and resistance of plants to pathogen attacks, although the exact pathways and mechanisms are not yet known $(41,42)$.

\section{Conclusion}

In line with the objectives of the study, analysis and results, the following conclusions and implications were made:

1. B. blumeana (kawayang tinik) extracts showed varying ranges of antimycotic activity against $A$. niger and $P$. chrysogenum. Thus, kawayang tinik can be a potential source of natural pharmacotherapeutic products against these pathogenic fungal species.

2. Ethanolic extracts of roots and inner culm exhibited the highest mean zone of inhibition (ZOI) against $A$. niger while ethanolic root and leaf extracts exhibited better inhibitory potentials against $P$. chrysogenum.

3. B. blumeana (kawayang tinik) extracts contain phytocompounds such as alkaloid, sterols, flavonoids, tannins and phenol. Hence, further studies are needed to specifically harness the compounds producing antifungal effects.

\section{Acknowledgements}

The researcher would like to extend her gratitude to Tarlac Agriculture University, Commission on Higher Education, Benguet State University, family and friends for their outmost support and encouragement.

\section{Conflict of interests}

Author do not have any conflict of interests to declare.

\section{References}

1. Center of Disease Control and Prevention (CDC). Antibiotic/Antimivrobial resistance (AR/AMR) [Internet]. CDC 24/7; 2020 July 20 [cited 2009 Jan 8]. Available from: https://www.cdc.gov/drugresistance/index.html

2. World Health Organization (WHO). WHO list of bacteria for which new antibiotics are urgently needed [Internet]. WHO Online; 2017 February 27 [cited 2018 Oct 14]. Available from: https://www.who.int/news/item/27-02-2017-who-publishes-listof-bacteria-for-which-new-antibiotics-are-urgently-needed 
3. Stuart GU. Philippine medicinal plant: kawayang tinik [Internet]. Philippine Medicinal Plant; 2018 January [cited 2018 Nov 30]. Available from: http://www.stuartxchange.org/Kauayan.html

4. Tantengco OAG, Condes MLC, Estadilla HHT, Ragragio EM. Ethnobotanical survey of medicinal plants used by Ayta communities in Dinalupihan, Bataan, Philippines. Pharmacogn J. 2018; 10(5): 859-70. https://doi.org/10.5530/pj.2018.5.145

5. Shukla R, Sumit G, Sajal S, Dwivedi PK, Mishra A. The medicinal importance of bamboo. International J Biopharm Phytochem Research. 2012;1(1):9-15.

6. Kalita C, Ganguly M, Devi A. Evaluation of antioxidant capacity and antimicrobial properties of ethnic Bambuseae species and identification of the active components. International Journal of Pharmaceutical and Biological Achieves. 2016.3(1):61-71.

7. Nguyen PT, Xuan TD, Ha PT, Tu anh TT, Khanh TD. Inhibitory effects of bamboo leaf on the growth of Pyricularia grisea fungus. Molecular Diversity Preservation International: Agriculture [Internet]. 2018 [cited 2018 Nov 30];8(92):1-8. https://doi.org/10.3390/agriculture8070092

8. Mahunu GK, Zhang H, Tibiru M, Qiya A, Xiaoyun Y, Zhao ZL. Bamboo leaf flavonoid enhances the control effect of Pichia caribbica against Penicillium expansum growth and Patulin accumulation in apples. Postharvest Biology and Technology [Internet]. 2018 [cited 2019 June 30];141:1-7. https://doi.org/10.1016/j.postharvbio.2018.03.005

9. Patil RN, Rothe SP. Antifungal activity of some fodder plants leaf extract. International Advanced Research Journal in Science, Engineering and Technology. 2016; 3(11):205-08.

10. Valentino MJG, Ganado LS, Ganado MR, Undan JR. Phytochemical screening and bio assay of the anti-microbial activity of three species of bamboo in Nueva Ecija, Philippines. Advances in Environmental Biology. 2015;9(24):389-96.

11. Darma R, Purnamasari M, Agustina D, Pramudito TE, Sugiharti M, Suwanto A. A strong antifungal-producing bacteria from bamboo powder for biocontrol of Sclerotium rolfsii in melon (Cucumis melo var. amanta). J Plant Pathol Microbiol [Internet]. 2016 [cited 2019 June 18];7(2):1-7. https://doi.org/10.4172/2157-7471.1000334

12. Shen X, Zheng D, Gao J, Hou C. Isolation and evaluation of endophytic fungi with antimicrobial ability from Phyllostachys edulis. Bangladesh Journal of Pharmacology [Internet]. 2012 $\begin{array}{llll}\text { [cited } & 2019 & \text { Jan }\end{array}$ https://doi.org/10.3329/bjp.v7i4.12068

13. Owolabi MS, Lajide L. Preliminary Phytochemical screening and antimicrobial activity of crude extracts of Bambusa vulgaris Schrad. ex J. C. Wendl. (Poaceae) from Southwestern Nigeria. American Journal of Essential Oils and Natural Products. 2015;3(1):42-45.

14. Wasnik DD, Tumane PM. Antibacterial activity of Bambusa bambose L. against multiple drug resistant (MDR) bacteria isolated from clinical specimen. International Journal of Pharmaceutical Sciences. 2014;25(1):215-18.

15. Wangawar SN, Shendarkar GR, Shelke DP, Daswad AK, Pohare JG, Roge AB. Phytochemical screening and antimicrobial activity of Dendrocalamus strictus leaves extracts. World Journal of Pharmaceutical Research. 2017;6(4):1029-41. https:// doi.org/10.20959/wjpr20174-8128

16. Tanaka A, Zhu Q, Tan H, Horiba H, Ohnuki K, Mori Y et al. Biological activities and phytochemical profiles of extracts from different parts of Bamboo (Phyllostachys pubescens). Molecules [Internet]. 2014 [cited 2018 June 30];1(19):8238-60. https://doi.org/10.3390/molecules19068238

17. Roxas CA. Bamboo research in the Philippines. In: Rao AN Ramanatha Rao V, (ed). Proceedings of Training Course cum workshop Bamboo - Conservation, Diversity, Ecogeography, Germplasm, Resource Utilization and Taxonomy; 2015 May 10; Yunnan, China. International Plant Genetic Resources Institute. ISBN: 92-9043-414-7.

18. Ambika $\mathrm{K}$, Rajagopal $\mathrm{B}$. In vitro antimicrobial and antiproliferative activity of Bambusa vulgaris. Internationa Journal of Pharmacy and Pharmaceutical Research 2017;9(1):10-22.
19. Chuah EL, Zakaria ZA, Suhaili Z, Abu bakar S and Desa MNM. Antimicrobial activities of plant extracts against Methicillin Susceptible and Methicillin - Resistant Staphylococcus aureus Journal of Microbiology Research [Internet]. 2014 [cited 2018 June https://doi.org/10.5923/j.microbiology.20140401.02

30];4(1):6-13

20. Selvamohan T, Ramadas V, Shibila S, Kishore S. Antimicrobial activity of selected medicinal plants against some selected human pathogenic bacteria. Pelagia Research Library Advances in Applied Science Research. 2012;3(5):3374-81.

21. Austria KC, Waing KGW, Valentino MJ. Anti-oxidant and antibacterial potentials of Bambusa blumeana J. A. and J. H. P Schultes and Bambusa vulgaris Schrad.ex Wendl. International Journal of Biology, Pharmacy and Allied Sciences. 2017;6(11):2175-88.

22. Kootstra AMJ, Huurman S. Extraction of steviol glycosides from fresh Stevia using acidified water: comparison to hot water extraction including purification. Application Center for Renewable Resources - Wageningen Plant Research. 2017;1:722.

23. Sule IO, Agbabiaka TO. Antibacterial effect of some plant extracts on selected Enterobacteriaceae. Ethnobotanical Leaflets. 2008;1(2):1035-42.

24. Lakshmanan K, Arumungam A, Mani R. Phytochemical screening and in - vitro antimicrobial activity of Vitex negundo L. var. purpurascens Sivar. and Mold Against Pathogenic Microorganisms. Drug Invention Today. 2012;4(12):667.

25. Islam MA, Alam MM, Choudhury ME, Kobayashi N, Ahmed MU. Determination of minimum inhibitory concentration (MIC) of cloxacillin for selected isolates of Methicillin- resistant Staphylococcus aureus (MRSA) with their antibiogram. Bangladesh Journal of Veterinary Medicine [Internet]. 2008 $\begin{array}{llll}\text { [Cited } & 2019 & \text { Nov } & \text { 24];6(1):121-26. }\end{array}$ https://doi.org/10.3329/bjvm.v6i1.1350v

26. Magaldi S, Mata- essayag S, Hartung de capriles C, Perez C Colella MT, Olaizola C et al. Well diffusion for antifungal susceptibility testing. Int J Infect Dis [Internet]. 2004 [cited 2018 June 30];1(8):39-45. https://doi.org/10.1016/j.ijid.2003.03.002

27. Scorzoni L, Benaducci T, Ameida AMF, Silva DHS, Da silva bolzani V, Gianinni MJSM. The use of standard methodology for the determination of antifungal activity of natural products against medical yeast Candida sp and Cryptococcus sp. Brazillian Journal of Microbiology [Internet]. 2007 [cited 2018 June 30];38(1):391-97. https://doi.org/10.1590/S151783822007000300001

28. Dash AK, Elmquist WF. Fluconazole. Analytical profile of drug substances and excipients [Internet]. 2001 [cited 2019 Sept 16];27:67-113. https://doi.org/10.1016/S1075-6280(01)27005-0

29. Coffie GY, Antwi-Boasiako C, Darkwa NA. Phytochemical constituents of the leaves of three bamboo (Poaceae) species in Ghana. Journal of Pharmacognosy and Phytochemistry. 2014;2(6):34-38.

30. Auwal MS, Saka S, Mairiga IA, Sanda KA, Shuaibu A, Ibrahim A. Preliminary phytochemical and elemental analysis of aqueous and fractionated pos extracts of Acacia nilotica (Thorn mimosa). Veterinary Research Forum. 2014;5(2):95-100.

31. Singh R. Chemotaxonomy: a tool for plant classification Journal of Medical Plant Studies. 2016;4(2):90-93.

32. Hao DC, Gu XJ, Xiao PG. 3 - Taxus medicinal resources: a comprehensive study. Medicinal Plants: Chemistry, Biology and Omics [Internet]. 2015 [cited 2018 June 30];12(2):97-136. https://doi.org/10.1016/j.chmed.2020.03.002

33. Zhang JJ, Liu M, Li Y, Zhou T, Xu DP. Nutritional values and biological activities of bamboo shoots and leaves. International Journal of Food and Nutrition Safety. 2016; 7(2):98-108.

34. Wang HX, Ng TB. Dendrocin, a distinctive antifungal protein from bamboo shoots. Biochemical and Biophysical Research Communications [Internet]. Extending the benefits of antifungal proteins from plants. [Internet]. 2003 [cited $2019 \mathrm{Ju}$ 30];307(3):750-55. 291X(03)01229-4

35. Zumdahl SS, Decoste DJ. Introductory Chemistry. Cengage Learning, Inc. United States of America; 2009. p. 477. 
36. Truong DH, Nguyen DH, Ta NTA, Bui AV, Do TH, Nguyen HC. Evaluation of the use of different solvents for phytochemical constituents, antioxidants and in vitro anti-inflammatory activities of Severinia buxifolia. Journal of Food Quality [Internet]. 2019 [cited 2019 Jul 16]; 1(1):1-9. https://doi.org/10.1155/2019/8178294

37. Pandey A, Tripathi S. Concept of standardization, extraction and pre phytochemical screening strategies for herbal drug. Journal of Pharmacognosy and Phytochemistry. 2014;2(5):11519.

38. Toan NP, Xuan TD, Thu ha PT, Tu anh TT, Khanh TD. Inhibitory effects of bamboo leaf on the growth of Pyricularia grisea fungus. Plant Disease Control and Agriculture [Internet]. 2018 [cited 2019 June 30];8(7):92 https://doi.org/10.3390/agriculture8070092

39. Cushnie T, Lamb JA. Antimicrobial activity of flavonoids. International Journal of Antimicrobial Agents [Internet]. 2005 [cited 2018 June 30];26(5):343-56. http://dx.doi.org/10.1016/j.ijantimicag.2005.09.002

40. Lee H, Woo ER, Lee DG. Apigenin induces cell shrinkage in Candida albicans by membrane perturbation. FEMS Yeast Research [Internet]. 2018 [cited 2019 Ju 19];18(1):1-9. https://doi.org/10.1093/femsyr/foy003

41. Marutescu L, Popa M, Saviuc C, Lazar V, Carmen Chifiriuc M. 8- Botanical pesticides with viricidal, bactericidal and fungicidal activity. In: Grumezescu AM, (ed). New Pesticides and Soil Sensors. Oxford, UK: Academic Press. 2017. p. 311-35. https://doi.org/10.1016/B978-0-12-804299-1.00009-6

42. Wafa N, Sofiane G, Mouhamed K. The antioxidant and antimicrobial activities of flavonoids and tannins extracted from Phlomis bovei De Noé. European Journal of Experimental Biology. 2016;6(3):55-61. 